\title{
Endogenous retroviral sequences are required for tissue-specific expression of a human salivary amylase gene
}

\author{
Chao-Nan Ting, Michael P. Rosenberg, ${ }^{1,3}$ Claudette M. Snow, Linda C. Samuelson, ${ }^{2}$ and \\ Miriam H. Meisler \\ Department of Human Genetics, University of Michigan, Ann Arbor, Michigan 48109-0618 USA; ${ }^{1}$ Department of Molecular \\ Biology, Bristol-Myers Squibb Pharmaceutical Research Institute, Princeton, New Jersey 08543 USA
}

The human salivary amylase genes are associated with two inserted elements, a $\gamma$-actin-processed pseudogene and an endogenous retroviral-like element. To test the contribution of these inserted elements to tissue specificity, 25 lines of transgenic mice carrying 10 amylase constructs were established. A 1-kb fragment of AMY1C $(-1003$ to +2$)$ was found to be sufficient for parotid-specific expression of a human growth hormone reporter gene. The $1-\mathrm{kb}$ fragment is entirely derived from inserted sequences. Deletion from -1003 to -826 resulted in reduced levels of transgene expression and loss of tissue specificity. The fragment -1003 to -327 was sufficient to transfer parotid specificity to the thymidine kinase promoter. The data demonstrate that the functional tissue-specific promoter of human AMY1C is derived from inserted sequences and that parotid expression can be conferred by sequences derived solely from the retrovirus. A role for retrotransposition in the evolution of gene regulation is indicated by these and other recent observations.

[Key Words: Human salivary amylase gene; inserted elements; endogenous retroviral sequences; tissue-specific expression; parotid-specific expression]

Received April 21, 1992; revised version accepted June 1, 1992

The amylase genes provide an interesting model for analysis of the evolution of tissue-specific isozymes. All mammalian species produce amylase in the pancreas, but the only mammals that also produce salivary amylase are primates, rodents, and lagomorphs (for review, see Meisler and Gumucio 1986). We have investigated the origin of salivary amylase expression in the human genome.

Salivary and pancreatic amylase are encoded by distinct but closely related genes (Schibler et al. 1982; Nishide et al. 1986). The human genome contains three salivary and two pancreatic amylase genes (Gumucio et al. 1988; Samuelson et al. 1988; Groot et al. 1989, 1991). Our earlier studies indicated that these genes were derived from one ancestral gene copy during primate evolution (Samuelson et al. 1990). During the evolution of this gene family, insertion of a processed $\gamma$-actin pseudogene in the proximal promoter region of the ancestral amylase gene was followed by a retroviral insertion. The $5^{\prime}$-flanking regions of the salivary amylase genes contain both $\gamma$-actin and retroviral sequences (Fig. 1). The transcriptional orientation of the retrovirus is opposite that of the amylase gene. Insertion of the retro-

\footnotetext{
${ }^{2}$ Present address: Department of Physiology, University of Michigan, Ann Arbor, Michigan 48109-0622 USA; ${ }^{3}$ Glaxo Research Inc., Research Park Triangle, North Carolina 27709 USA.
}

viral element is correlated with a switch from pancreatic to parotid expression and excision of the retrovirus with reversion to pancreatic expression (Samuelson et al. 1990). The exclusive association of the provirus with salivary amylase genes led us to propose that this inserted element may be responsible for salivary amylase expression in primates.

The amylase-associated retroviral-like elements belong to the family of human endogenous retroviruses designated 4-1, or HERV-E, which contains $\sim 50 \mathrm{mem}$ bers (Rabson et al. 1983; Repaske et al. 1985; Larson et al. 1989). In the current study we tested the role of retroviral sequences in regulating expression of the human salivary amylase gene in transgenic mice.

\section{Results}

Transcription of AMY1C in the parotid gland of transgenic mice

Three genomic fragments containing the intact salivary amylase gene AMY1C with different amounts of 5'flanking sequence were microinjected into fertilized mouse eggs as described in Materials and methods. The structures of the fragments are represented in Figure 2A. Transgenic mice were identified by polymerase chain reaction (PCR) of genomic DNA. RNA was isolated from 
Ting et al.

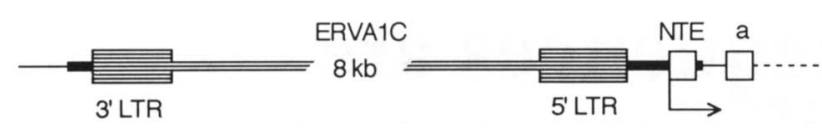

Figure 1. Structure of the human salivary amylase gene AMY1C. Insertions of the $\gamma$-actin pseudogene (solid bar) and the retrovinus ERVAlC occurred $\sim 40$ million years ago (Samuelson et al. 1990). ( $\square$ |Exon a and the NTE; the rest of the gene is not shown. The major start site for transcription is indicated by an arrow. Insertion of the retrovirus apparently activated a cryptic promoter within the $\gamma$-actin pseudogene.

tissues of transgenic animals and human amylase transcripts were assayed using riboprobe 1B-2 which contains the nontranslated exon (NTE) and the first coding exon (exon a) of AMY1C (Fig. 3). Human parotid RNA protects four major fragments from this probe (Fig. 3, lane 1). Parotid RNA from line 6713, carrying the N2 transgene, protected the same fragments (lanes 5-7), indicating that the human gene is transcribed accurately.
Parotid RNA from nontransgenic mice does not protect this probe (Fig. 3, lane 11), demonstrating the species specificity of the assay. Another NTE probe was protected by parotid RNA from three independent lines carrying N2 and one line carrying N2-Apa, but not by four independent transgenic lines carrying the smallest fragment, N2-Bam (Fig. 4). All samples contained comparable levels of mouse amylase mRNA on Northern blots (data not shown). These results indicate that sequences required for expression in the parotid gland are located between the ApaI site at $-10 \mathrm{~kb}$ and the BamHI site at $-826 \mathrm{bp}$.

\section{Tissue specificity of AMY1C expression}

The major site of transcription of these fragments was the parotid gland. In lines carrying the N2 construct, human amylase transcripts could not be detected in brain, submaxillary gland, stomach, intestine, pancreas, liver, spleen, kidney, muscle, or fat with the ribonu-
A

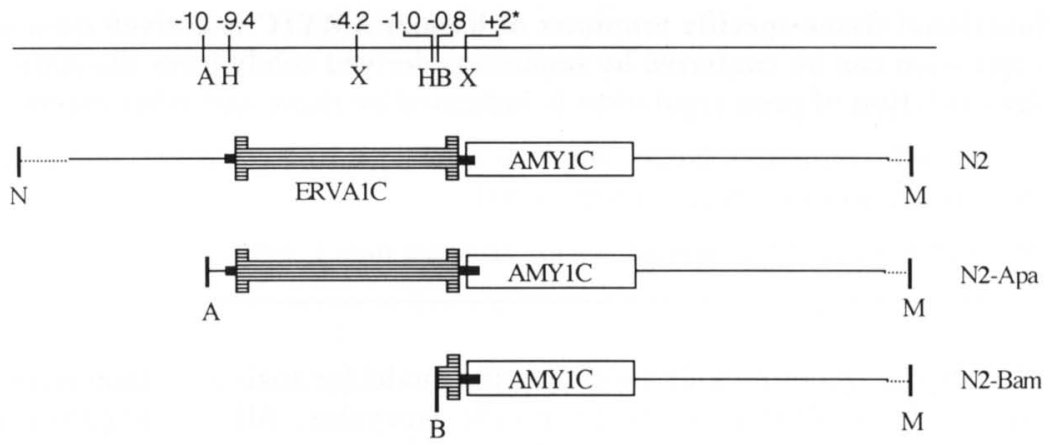

B

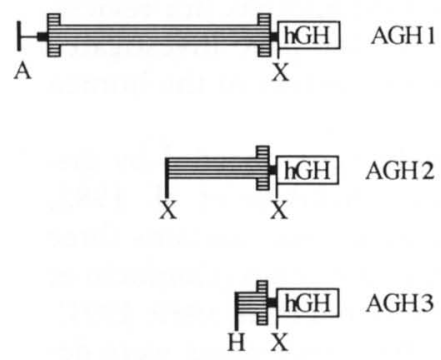

Figure 2. Salivary amylase constructs studied in transgenic mice. (A) Genomic fragments derived from the cosmid N2. Fragments were isolated from the cosmid clone N2 as described in Materials and methods. Vector sequences in the fragments are indicated by the dotted line. (B) Amylase/hGH fusion genes. The AGH constructs include the amylase promoter to nucleotide +2 . The ATK constructs contain the tk promoter. (Striped box) Endogenous retrovirus ERVA1C with LTRs shown as expanded regions; (solid box) tk promoter; (A) ApaI; (B) BamHI; (H) HindIII; (M) MluI; (N) NruI; (X) XbaI.

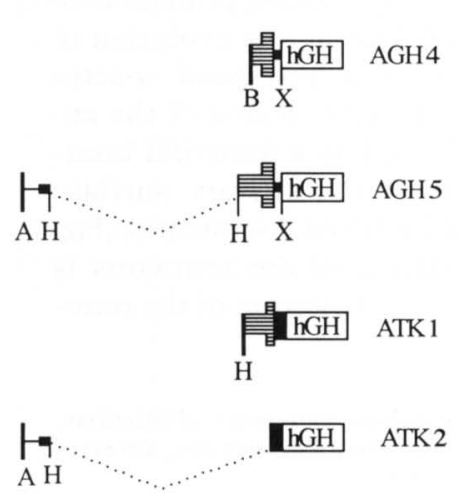




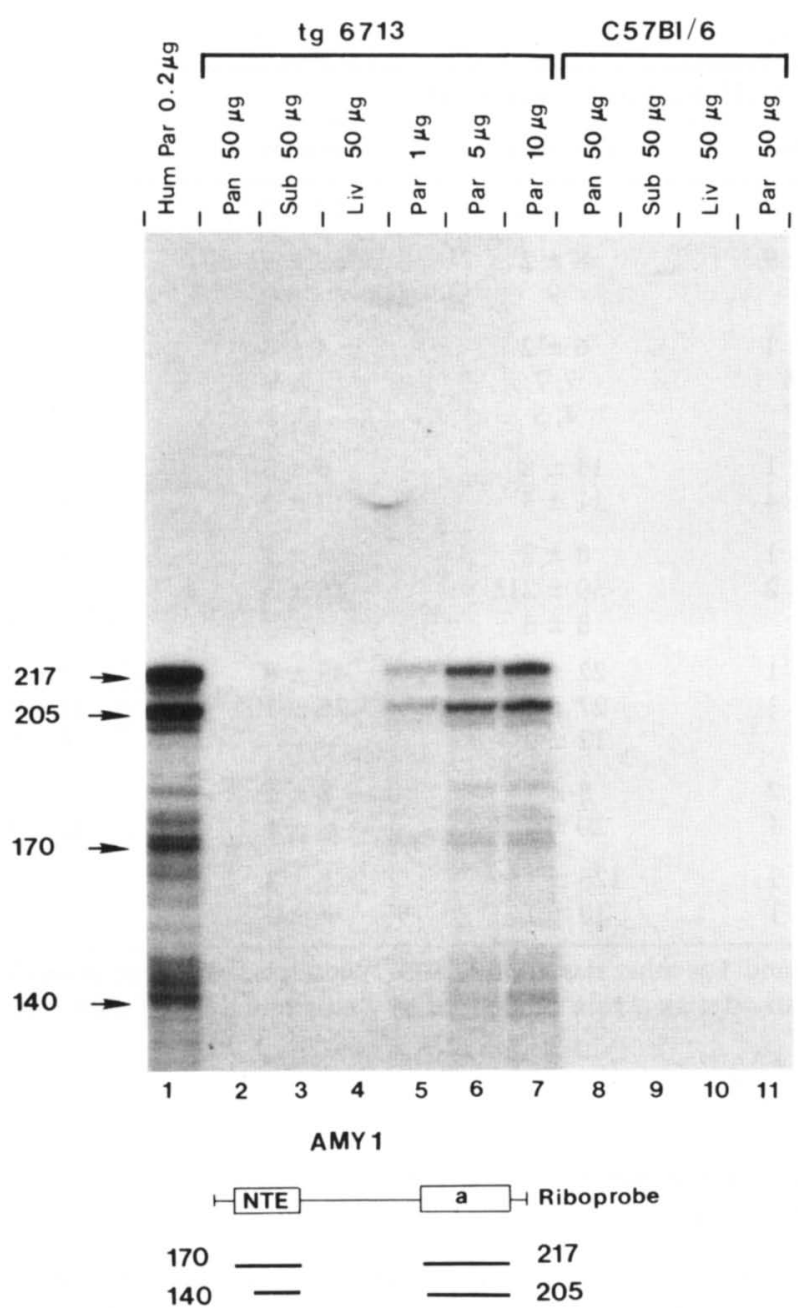

Figure 3. Tissue distribution of transcripts from the N2 transgene. Total RNA was prepared from tissues of N2 transgenic line 6713 and nontransgenic $\mathrm{C} 57 \mathrm{BL} / 6 \mathrm{~J}$ mice. The structure of the 1B-2 riboprobe used in the RNase protection assay is indicated (Samuelson et al. 1988). The 140- and 170-bp fragments are derived from the NTE, which is initiated at two major transcription start sites; the 217 - and 205-bp products are derived from exon a (Samuelson et al. 1988). Transgenic and nontransgenic parotid RNA contained comparable amounts of intact mouse amylase mRNA, which was detected by Northern blotting and protection assays (not shown). (Lane 1) Human parotid; (lanes 2-7) transgenic; (lanes 8-11) C57BL/6J. (Par) Parotid; (pan) pancreas; (sub) submaxillary gland; (liv) liver.

clease protection assay (Fig. 3; C.-N. Ting and M.H. Meisler, unpubl.). A low level of transcripts, $\sim 1 \%$ of the level in the parotid gland, was present in lung and in samples containing ovary and oviduct. Salivary amylase has been detected in human lung and ovarian tumors (Hayashi et al. 1986).

Three lines carrying the construct N2-Bam did not produce amylase transcripts in any of the 10 tissues tested. In the fourth line, 9053, a low level of aberrant transcripts which lacked the NTE were detected in the parotid gland and several other tissues.
Using riboprobes complementary to the $5^{\prime}$ and $3^{\prime}$ long terminal repeats (LTRs), we were unable to detect retroviral transcripts in tissues of transgenic mice or in human parotid RNA (C.-N. Ting and M.H. Meisler, unpubl.).

\section{Expression of human growth hormone fusion genes}

To further localize sequences required for expression in the parotid gland, fragments containing the AMYIC promoter and various $5^{\prime}$-flanking sequences were ligated to a human growth hormone (hGH) reporter gene (Fig. 2B). The expression of each construct was tested in two or three independent transgenic lines, by use of a speciesspecific radioimmunomatrix assay for $h \mathrm{GH}$. Constructs AGH1, AGH2, and AGH3, with 10, 4.2, and $1 \mathrm{~kb}$ of 5'flanking DNA, respectively, were all expressed in the parotid gland (Table 1). Although the level of expression of each construct varied by as much as 20 -fold in different independent lines, the range of expression for the three constructs was very similar. These observations indicate that the $1-\mathrm{kb}$ amylase fragment in AGH3 con-

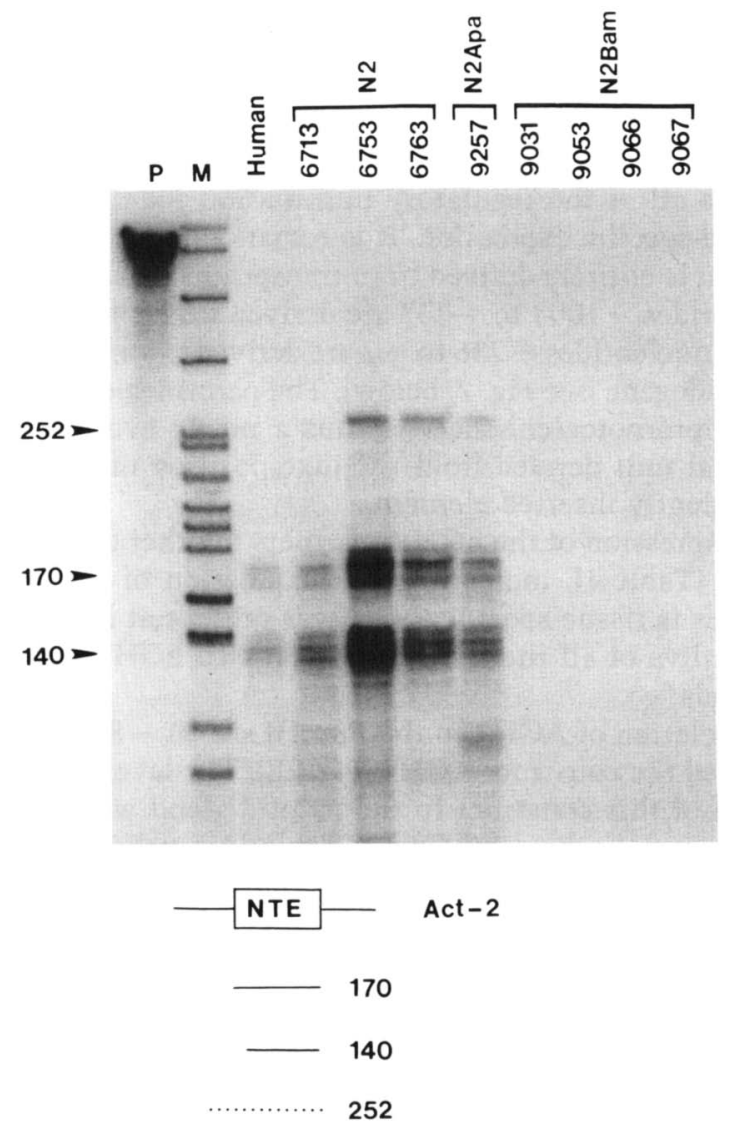

Figure 4. Protection of the NTE by parotid RNA from transgenic mice. Parotid RNA samples from each transgenic line were hybridized with the Act- 2 riboprobe containing the NTE from AMY1C. Assays were carried out as described in the legend to Fig. 3 and Materials and methods. 
Ting et al.

Table 1. Expression of hGH in transgenic mice carrying hGH constructs

\begin{tabular}{|c|c|c|c|c|c|c|}
\hline \multirow[b]{2}{*}{ Transgene } & \multirow[b]{2}{*}{ Line } & \multicolumn{5}{|c|}{ hGH (ng/g tissue wet weight) ${ }^{a}$} \\
\hline & & parotid & heart & pancreas & spleen & liver \\
\hline None & $\mathrm{C} 57 \mathrm{BL} / 6 \mathrm{~J}$ & $9 \pm 1(7)$ & $5 \pm 3$ & $9 \pm 6$ & $14 \pm 3$ & $3 \pm 1$ \\
\hline AGH1 & $\begin{array}{l}13984 \\
13987\end{array}$ & $\begin{array}{c}270 \pm 22(7) \\
1400(1)\end{array}$ & $\begin{array}{c}33 \pm 9 \\
-\end{array}$ & $\begin{array}{c}8 \pm 2 \\
9\end{array}$ & $\begin{array}{c}38 \pm 9 \\
-\end{array}$ & $\begin{array}{c}19 \pm 3 \\
7\end{array}$ \\
\hline AGH2 & $\begin{array}{l}19671 \\
19683 \\
14114\end{array}$ & $\begin{array}{c}260 \pm 10(7) \\
530,280(2) \\
3900 \pm 270(4)\end{array}$ & $\begin{array}{l}3 \pm 1 \\
4,6 \\
5,7\end{array}$ & $\begin{array}{c}6 \pm 2 \\
7,7 \\
4,5\end{array}$ & $\begin{array}{r}4 \pm 3 \\
2,9 \\
3,2\end{array}$ & $\begin{array}{l}5 \pm 3 \\
4,8 \\
5,2\end{array}$ \\
\hline AGH3 & $\begin{array}{l}16694 \\
16704\end{array}$ & $\begin{array}{c}150 \pm 10(4) \\
3700 \pm 100(4)\end{array}$ & $\begin{array}{r}5 \pm 1 \\
11 \pm 4\end{array}$ & $\begin{array}{l}14 \pm 8 \\
11 \pm 5\end{array}$ & $\begin{array}{r}6 \pm 3 \\
12 \pm 2\end{array}$ & $\begin{array}{l}7 \pm 4 \\
8 \pm 2\end{array}$ \\
\hline AGH4 & $\begin{array}{l}864 \\
866 \\
889\end{array}$ & $\begin{array}{c}8 \pm 1(7) \\
25 \pm 3(4) \\
30 \pm 4(10)\end{array}$ & $\begin{array}{r}4 \pm 1 \\
11 \pm 2 \\
-\end{array}$ & $\begin{aligned} 8 & \pm 2 \\
50 & \pm 21^{\star} \\
8 & \pm 3\end{aligned}$ & $\begin{array}{r}4 \pm 1 \\
16 \pm 5 \\
-\end{array}$ & $\begin{array}{l}6 \pm 3 \\
7 \pm 2 \\
4 \pm 1\end{array}$ \\
\hline AGH5 & $\begin{array}{l}272 \\
269 \\
266\end{array}$ & $\begin{array}{c}270 \pm 20(6) \\
380 \pm 40(7) \\
2600 \pm 250(3)\end{array}$ & $\begin{array}{c}10 \pm 1 \\
11 \pm 1 \\
-\end{array}$ & $\begin{array}{l}22 \pm 5 \\
27 \pm 6 \\
12 \pm 2\end{array}$ & $\begin{aligned} 45 & \pm 8 \\
25 & \pm 10^{\star} \\
& \end{aligned}$ & $\begin{aligned} 7 & \pm 1 \\
11 & \pm 1 \\
5 & \pm 2\end{aligned}$ \\
\hline ATK1 & $\begin{array}{r}19021 \\
128\end{array}$ & $\begin{array}{r}700 \pm 140(4) \\
1300 \pm 150(5)\end{array}$ & $\begin{array}{l}12 \pm 2 \\
10 \pm 1\end{array}$ & $\begin{array}{r}8 \pm 1 \\
20 \pm 2\end{array}$ & $\begin{array}{l}8 \pm 2 \\
6 \pm 1\end{array}$ & $\begin{array}{r}7 \pm 1 \\
40 \pm 3\end{array}$ \\
\hline ATK2 & $\begin{array}{l}19636 \\
19635\end{array}$ & $\begin{array}{l}8 \pm 1|4\rangle \\
9 \pm 1(4)\end{array}$ & $\begin{array}{l}3 \pm 1 \\
7 \pm 1\end{array}$ & $\begin{array}{c}126 \pm 15 \\
10 \pm 1\end{array}$ & $\begin{array}{l}8 \pm 2 \\
4 \pm 1\end{array}$ & $\begin{array}{l}2 \pm 1 \\
3 \pm 1\end{array}$ \\
\hline
\end{tabular}

${ }^{a}$ Values are means \pm S.E. $(n)$ The number of animals assayed for parotid gland. For other tissues, $n=4-6$. When less than three animals were available, the individual values are reported. Values marked with an asterisk ( $\left.{ }^{*}\right)$ are influenced by a single individual with high activity.

tains all of the regulatory information required for parotid-specific expression. It is remarkable that this fragment is entirely derived from transposon sequences: $\mathrm{Nu}$ cleotides -1003 to -237 are derived from the provirus, and nucleotides -236 to +2 are derived from the $\gamma$-actin pseudogene (see Fig. 7, below). The parotid-specific amylase promoter/enhancer is thus a newly evolved functional unit derived from the juxtaposition of two independently inserted elements.

Expression of the hGH constructs in other tissues was low (Table 1), indicating that expression of the fusion genes is tissue specific. hGH was present at high levels in saliva of all the mice that expressed hGH in parotid glands.

Deletion of AGH3 to the BamHI site at -826 bp generated the construct AGH4 (Fig. 2B). The level of expression of this construct in the parotid gland was reduced almost to background levels (Table 1). Furthermore, the expression of this construct was not tissue specific ( $\mathrm{Ta}$ ble 1). Comparison of the expression of $\mathrm{AGH} 3$ and AGH4 indicates that the region -1003 to -826 contains a regulatory element that is required for expression in the parotid gland. This sequence is derived from the $5^{\prime}$-untranslated region of the provirus (see Fig. 7, below).

To test the function of endogenous genomic sequences located upstream of the provirus, an 0.6-kb ApaI-HindIII fragment $(-10$ to $-9.4 \mathrm{~kb})$ was ligated to AGH3 to generate AGH5. The level of expression of AGH3 and AGH5 did not differ significantly (Table 1), indicating that this fragment does not contain regulatory elements.
Transfer of parotid specificity to a heterologous promoter

To determine whether the amylase promoter is required for parotid-specific expression, two constructs substituting the herpes virus thymidine kinase (tk) promoter were studied. In ATK1, the AMY IC fragment -1003 to -327 was ligated to the tk promoter (Fig. 2B). ATK1 was expressed specifically in the parotid gland of two independent lines, with a level of activity comparable to that of the constructs containing the AMYIC promoter (Table 1). The region -1003 to -327 thus appears to contain all of the parotid-specific enhancer activity of the larger constructs.

As a negative control, the 600-bp ApaI-HindIII fragment $(-10$ to $-9.4 \mathrm{~kb})$ lacking enhancer activity was placed in a similar position (ATK2, Fig. 2B). ATK2 was not expressed in the parotid gland or in other tissues (Table 1). The lack of expression of this construct demonstrates that the growth hormone and tk sequences do not produce parotid-specific expression of ATK1.

\section{Common sequence elements in the AMY1C enhancer}

AMYlC sequence -1003 to -752 is compared with the corresponding region of the human endogenous retrovirus 4-1 in Figure 5. The high degree of sequence identity $(85 \%)$ demonstrates that this region is derived from proviral sequences. The sequence was also compared with seven other genes that are expressed in the parotid gland. 


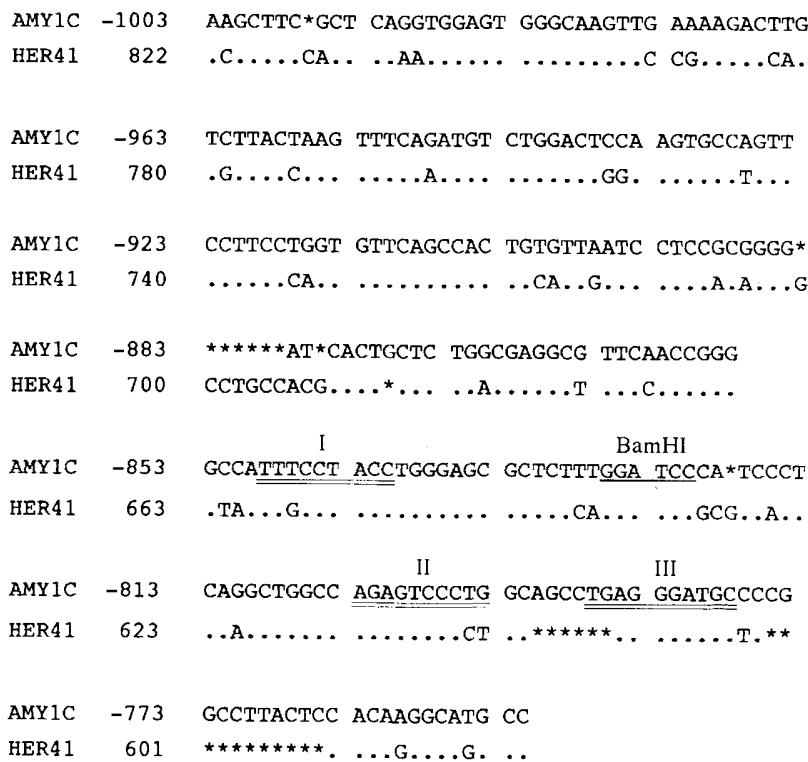

Figure 5. Sequence comparison of AMY1C and the human endogenous retrovirus HER 4-1. Dots represent identity with the AMY1C sequences. Asterisks mark deleted nucleotides. Three elements shared by other parotid-expressing genes are doubly underlined and numbered I, II, and III. The recognization sequence for restriction enzyme $B a m H I$ is underlined. The HER 4-1 sequence is from Repaske et al. (1985). The AMY1C sequence reported here differs at six nucleotides from the sequence reported by Emi et al. (1988).

Approximately $1 \mathrm{~kb}$ of $5^{\prime}$-flanking region from each gene was searched by computer to detect 10-bp segments with $>85 \%$ sequence identity to this region of AMYlC. Three common elements were detected (Table 2). The arrangement of these elements in the human AMY1C and proline-rich protein (PRP) genes is nearly identical, and the two unrelated genes differ at only 3 of 29 nucleotides within the elements. These elements do not appear to be related to known transcriptional regulatory sequences. Although functional information is not available for the other genes, the sequence similarity suggests that the elements may be important components of the amylase enhancer.

\section{Parotid nuclear proteins bind the amylase enhancer}

Because deletion of the fragment -1003 to -826 reduces hGH expression in the parotid gland, we tested the affinity of this fragment for nuclear proteins. Parotid nuclear extracts contain protein which binds specifically to this fragment (Fig. 6). Binding was specifically competed by the same fragment (lanes 3-5) and by the subfragment -885 to -826 which contains conserved element I/data not shown). Liver nuclear extracts do not contain binding activity (lane 9).

\section{Discussion}

We have demonstrated that sequences derived from the endogeneous retroviral-like element ERVA1C are responsible for the tissue specificity of the adjacent AMY1C gene. The AMY1C sequence -1003 to +2 , which functions as a parotid-specific enhancer/promoter in vivo, is composed of sequences derived entirely from retroviral and $\gamma$-actin inserts (Fig. 7). This tissue-specific regulator is thus derived from the juxtaposition of two unrelated sequences. Transfer of parotid specificity to a heterologous promoter demonstrated the autonomy of enhancer-like elements within the region -1003 to -327 . This is the first localization of parotid-specific regulatory elements of which we are aware.

The results confirm the earlier prediction that was based on comparison of the structures of the five human amylase genes. The three salivary amylase genes are each associated with an intact retroviral element. The two pancreatic amylase genes either lack retroviral sequences (AMY2B) or contain a solo LTR as a result of excision of the retrovirus (AMY2A) (Samuelson et al. 1990). The gene structures are consistent with a sequence of events in which insertion of the retrovirus converted a pancreatic amylase gene like AMY2B into a salivary-specific gene, and excision of the retrovirus resulted in a return to pancreas-specific expression of AMY2A. The combined structural and functional information provide strong evidence for the role of retroviral insertion in the evolution of tissue specificity of this gene family.

Comparison of the 5'-flanking region of AMY1C and

Table 2. Common elements in human and mouse salivary gland-specific genes

\begin{tabular}{|c|c|c|c|}
\hline Gene & I & II & III \\
\hline hAMY 1C & -849 TTTCCTACC & -802 AGAGTCCCTG & -784 TGAGGGATGC \\
\hline hPRP & $-119 . A \ldots \ldots$ & $-93 \ldots \ldots$ A. & $-77 \ldots \ldots$ A. \\
\hline $\mathrm{mPsp}$ & $-697 * . G \ldots \ldots$ & $-16 \ldots A \ldots A$. & $-675 * \ldots \ldots$ ATG \\
\hline $\mathrm{mPrp}$ & -332 .A....T & $-92 * \ldots \mathrm{T} \ldots \ldots \mathrm{A}$ & $-104 * \ldots$ T.A.G \\
\hline
\end{tabular}

One kilobase of $5^{\prime}$-flanking sequence from each gene was compared with AMY1C nucleotides -1003 to -752 . Three regions with $>85 \%$ sequence identity were identified. $\left({ }^{*}\right)$ Reverse orientation; (hPRP) human proline-rich protein gene (Kim and Maeda 1986); (mPsp) mouse parotid secretory protein gene (Shaw and Schibler 1986); (mPrp) mouse proline-rich protein gene (Ann and Carlson 1985). 
Ting et al.

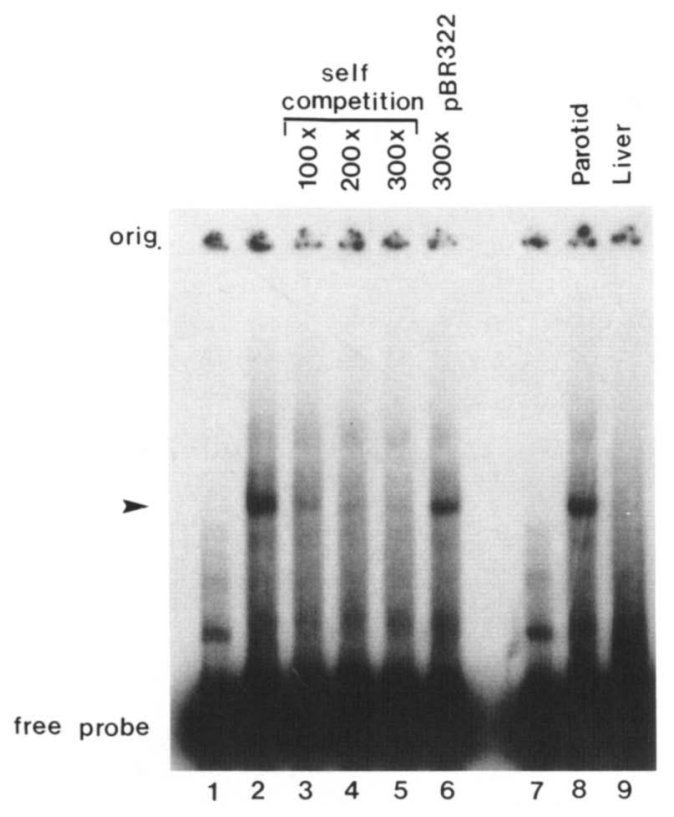

Figure 6. Specific binding of parotid nuclear protein by the AMYIC parotid enhancer. The HindIII-BamHI fragment $(-1003$ to -826$)$ was radiolabeled and incubated with $10 \mu \mathrm{g}$ of nuclear protein, as described in Materials and methods. The nonspecific competitor was a 120-bp fragment from pBR322 (Howard et al. 1989). (Lanes 1,7) Probe alone; (lane 8) nuclear extract from mouse liver; (lanes 2-6, 9) nuclear extract from mouse parotid.

other salivary-specific genes identified three short elements that are present in a similar array in the proximal promoter region of the human PRP gene. Deletion of element I resulted in reduced parotid expression in vivo. It will be of great interest to determine whether these three elements are sufficient for parotid enhancer activity and whether they are shared by other salivary-specific genes.

One surprising implication of these studies is that parotid specificity has arisen independently in the mouse and human genomes, as the $\gamma$-actin and proviral insertions in the human gene were acquired after the divergence of rodents and primates. This is consistent with the closer sequence similarity of the salivary and pancreatic amylase genes within each species, compared with the similarity of the orthologous genes (for review, see Meisler and Gumucio 1986). The fact that the mouse salivary amylase gene is transcribed from an upstream NTE that is not present in the pancreatic amylase gene (Schibler et al. 1982) suggests that the mouse gene, like human AMYIC, may be derived from a preexisting pancreatic amylase gene.

The independent, convergent evolution of salivary amylase in human and mouse indicates that there has been strong positive selection for salivary amylase at some points during mammalian evolution. Because the enzymatic activities of pancreatic and salivary amylases are quite similar, there is no obvious advantage to dupli- cation of the digestive activity per se in two different organs. One interesting hypothesis is that the sweet taste of the sugars produced by the action of salivary amylase in the mouth could aid in the recognition of nutritious food sources. Another potentially selectable function for salivary amylase in facilitating oral microbial colonization has been proposed (Scannapieco et al. 1990).

In the evolution of tissue-specific isozymes, three mechanisms for duplication of coding sequence have been identified. The most common mechanism, as observed for the amylase genes, is gene duplication followed by divergence of regulation of one gene copy. Several testis-specific isozymes have been generated by a different mechanism, that is, retroposition of processed transcripts with the new regulatory sequences provided by the insertion site (Boer et al. 1987; McCarrey and Thomas 1987; Dahl et al. 1990|. In the third case, a single structural gene is regulated by alternative promoters with different tissue specificity (Schibler and Sierra 1987). In all of these situations, the mechanism of origin of the new regulatory elements is of central importance to understanding the evolution of diversity. For the human amylase genes, we have now demonstrated that retroviral insertion contributed to altered tissue specificity.

It has been argued that changes in gene regulation may be more important to the process of speciation than the gradual accumulation of structural variation. How general is the role of retroviral insertion in changing gene expression? Two additional examples have recently been described: insertion of an LTR-derived hormone-response element upstream of a mouse complement-related gene (Stavenhagen and Robins 1988; Adler et al. 1991), and insertion of an LTR-derived nonspecific promoter upstream of the gonad-specific chicken aromatase gene (Matsumine et al. 1991). These examples suggest that retroviral-like elements and other DNA inserts could be important vectors of rapid qualitative changes leading to complexity and diversity. The presence of thousands of copies of such elements in the mammalian

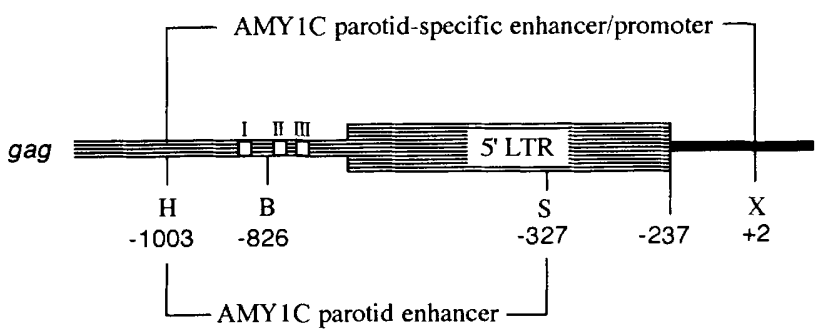

Figure 7. The functional parotid-specific promoter of AMY1C is derived entirely from two inserted elements. Nucleotides -1003 to -237 are derived from the retrovirus. Nucleotides -236 to +2 are derived from the $3^{\prime}$-untranslated region of a $\gamma$-actin-processed pseudogene. The first codon of the retroviral gag gene is located at nucleotides -1245 to -1247 . The complete sequence of this region is available (Fig. 5; Emi et al. 1988; Samuelson et al. 1988; Samuelson et al. 1990). (H) HindIII; (X) XbaI; (B) BamHI; (S) StuI. 
genome, some of which are capable of transposition (Dombroski et al. 1991; Evans and Palmiter 1991), is consistent with more widespread effects than are currently appreciated.

The human salivary amylase enhancer described here has potential applications in basic and applied research. Direction of oncogene expression to the parotid gland may be used to develop cultured cell lines that retain some of the differentiated characteristics of salivary acinar cells. Such lines are not currently available and would be quite useful in salivary research. Treatments for oral disease may be tested by expression of potentially therapeutic proteins in transgenic animals. Finally, isolation of valuable proteins from saliva of transgenic animals could be practical in some situations.

\section{Materials and methods}

\section{Transgenic lines}

DNA fragments were electroeluted from agarose gels and prepared for microinjection as described previously (Osborn et al. 1987). Fertilized mouse eggs were obtained from matings of (C57BL/6 $\times \mathrm{C} 3 \mathrm{H} / \mathrm{He} / \mathrm{F}_{1}$ mice, except for constructs AGH3 and ATK1, which utilized $(\mathrm{C} 57 \mathrm{BL} / 6 \times \mathrm{SJL}) \mathrm{F}_{1}$ mice. Transgenic founders were crossed to inbred strain $\mathrm{C} 57 \mathrm{BL} / 6 \mathrm{~J}$, and 25 independent transgenic lines were established. Tissues for analysis were obtained from heterozygous transgenic individuals from generations $\mathrm{N} 1, \mathrm{~N} 2$, and N3. The transgene copy numbers in the transgenic lines were estimated by Southern blotting of genomic DNA with transgene-specific probes and comparison with standards as described previously (Jones et al. 1989). Most lines contained between one and five copies of the transgene, with a higher copy number in lines 9257 (20-25 copies), 13987 (10-15 copies), and 889 (15-20 copies). Mice carrying the hGH fusion genes were within the normal range of body weight.

\section{Construction of hGH fusion genes}

To generate the constructs in Figure 2, a 2.1-kb BamHI-EcoRI fragment containing the hGH structural gene was isolated from pOGH (Nichols Institute, Los Angeles, CA) and subcloned into the vector pSP72 (Promega). The 12-kb DNA fragment extending from the $X h o I$ site $(-12 \mathrm{~kb})$ to the $X b a \mathrm{I}$ site $(+2 \mathrm{bp})$ of AMY1C was inserted upstream of the hGH gene in pSP72 to generate the cloning intermediate pXXGH. Constructs AGH1, $\mathrm{AGH} 2, \mathrm{AGH} 3$, and AGH4 were isolated from pXXGH by digestion with EcoRI and ApaI, XbaI, HindIII, or BamHI, respectively. pAGH5 was constructed by digestion of pXXGH with HindIII and religation. The AGH5 fragment was isolated after digestion of pAGH5 with ApaI and EcoRI. The 2.9-kb fragment ATK1 was isolated by HindIII and EcoRI digestion of a derivative of pAGH5 in which the AMY1C promoter $(-326$ to +2$)$ was replaced with herpes simplex virus tk $(-110$ to +20$)$ (McKnight 1982). pATK2 was generated from pAGH5 by replacing AMY1C $(-1003$ to +2$)$ with tk $(-159$ to +56$)$. The ATK2 fragment was isolated from pATK2 by digestion with ApaI and EcoRI.

\section{Identification of transgenic individuals by PCR of genomic DNA}

Transgenic individuals were identified by PCR of genomic DNA isolated from the tail. The AMY1C primers HTA-C (5'-
CAC CAT TGG GTT CTG CTG GGC TCA GTA TTC- $3^{\prime}$ ) and HTA-N (5'-CGC TCA CAT TCA AGA GCA ATA TCA ACC CAT-3') amplify exon a of AMYIC from +584 to + 704 (Gumucio et al. 1988) and do not amplify mouse amylase. Reactions contained $1 \mu \mathrm{g}$ of genomic DNA and 2 units of Taq polymerase in $10 \mathrm{~mm}$ Tris- $\mathrm{HCl}$ (pH 8.3), $50 \mathrm{mM} \mathrm{KCl}, 1.5 \mathrm{mM} \mathrm{MgCl} 2,0.01 \%$ BSA, with $0.2 \mathrm{~mm}$ dNTPs and $0.5 \mu \mathrm{M}$ concentration of each primer. Reactions were subjected to 24 cycles alternating between $94^{\circ} \mathrm{C}(75 \mathrm{sec})$ and $72^{\circ} \mathrm{C}(3 \mathrm{~min})$. The 110 -bp product was detected on $6 \%$ polyacrylamide gels stained with ethidium bromide. PCR primers for the hGH gene amplify a 330-bp fragment $(+410$ to +729$)\left(\right.$ DeNoto et al. 1981): hGH-C $\left(5^{\prime}\right.$-CCA CAA ATT CCC TTA TCC AGG CTT TTT GAC-3') and hGH-N (5'TAC TTC TGT TCC TTT GGG ATA TAG GCT TCT-3'). Amplication of hGH was carried out with the solutions described above for 29 cycles at $94^{\circ} \mathrm{C}(30 \mathrm{sec}), 60^{\circ} \mathrm{C}(90 \mathrm{sec})$, and $72^{\circ} \mathrm{C}(2$ $\mathrm{min} \mid$. The products were analyzed on polyacrylamide gels as described above.

\section{Ribonuclease protection assay}

RNA was isolated from various tissues by homogenization in guanidine thiocyanate, followed by centrifugation through cesium chloride as described by Samuelson et al. (1988). RNA concentrations were determined by $\mathrm{OD}_{260}$, and quality was assessed by examination of the $28 \mathrm{~S}$ and $18 \mathrm{~S}$ rRNA bands after electrophoresis through agarose and staining with ethidium bromide. Human-specific riboprobes $1 \mathrm{~B}-2$ and Act-2 were used to detect the presence of the human amylase transcripts by ribonuclease protection assay as described previously (Samuelson et al. 1988). Single-stranded and uniformly labeled riboprobes were generated by use of $\left[\alpha^{-32} \mathrm{P}\right] \mathrm{UTP} / 800 \mathrm{Ci} / \mathrm{mM}, \mathrm{Am}-$ ersham) according to the procedure recommended by Promega Biotec. The protected products were detected by autoradiography after electrophoresis in $6 \%$ polyacrylamide gels with $8 \mathrm{M}$ urea. Parotid RNA samples were prepared from pooled glands of six individuals.

\section{Radioimmunomatrix assay of hGH}

Tissue samples from transgenic mice (15-60 mg wet weight) were homogenized in $1 \mathrm{ml}$ of $0.85 \% \mathrm{NaCl}$ with a Polytron homogenizer for $5 \mathrm{sec}$ and centrifuged at $4^{\circ} \mathrm{C}$ for $5 \mathrm{~min}$. Supernatant hGH was measured with a solid-phase two-site radioimmunomatrix assay kit by use of ${ }^{125}$ I-labeled and biotin-coupled anti-hGH antibodies (Nichols Institute). Samples were counted in a Beckman Gamma Counter 5500. Tissue homogenates were diluted to levels within the linear range of the assay, which was $1-50 \mathrm{ng} / \mathrm{ml}(\sim 500-25,000 \mathrm{cpm})$.

Saliva was collected from mice $5 \mathrm{~min}$ after intraperitoneal injection of $0.1 \mathrm{ml}$ of pilocarpine nitrate (Sigma) $(6 \mathrm{mg} / \mathrm{ml}$ ). Fifty microliters of saliva was diluted with $200 \mu \mathrm{l}$ of $0.85 \% \mathrm{NaCl}$ for radioimmunomatrix assay.

\section{Sequence analysis}

Sequencing reactions were carried out by use of the Sequenase kit (U.S. Biochemical, v. 2.0). The 252-bp HindIII-SphI fragment containing nucleotides -1003 to -752 of AMYlC was subcloned into pSP72, and both strands were sequenced by using the T7 and SP6 primers. Sequencing products were resolved on a $6 \%$ polyacrylamide gel with $8 \mathrm{M}$ urea. Sequence alignments of AMY1C and other genes were performed on an IBM PC computer with the aid of Pustell DNA analysis software (International Biotechnology, Inc.) 


\section{Isolation of nuclei and gel retardation assay}

Parotid glands were dissected from 60 mice and stored frozen at $-70^{\circ} \mathrm{C}$. Nuclei were prepared from frozen tissue by the method of Blobel and Potter (1966), with modifications. Frozen tissues were pulverized in a precooled mortar and pestle and homogenized in buffer A with $0.32 \mathrm{M}$ sucrose and centrifuged at low speed for $30 \mathrm{sec}$ to remove debris and unbroken cells. The supernatant was carefully layered on an equal volume of buffer $\mathrm{A}$ containing $0.88 \mathrm{M}$ sucrose and centrifuged at $800 \mathrm{~g}$ for $5 \mathrm{~min}$ at $4^{\circ} \mathrm{C}$. The nuclear pellet was collected, and protein was extracted by the method of Dignam et al. (1983). Dialysis and quantitation of protein were carried out as decribed by Howard et al. (1989).

Isolated DNA fragments were radiolabeled with $\left[\alpha{ }^{32} \mathrm{P}\right] \mathrm{dCTP}$ by use of the Klenow fragment of DNA polymerase (Boehringer Mannhem). Gel retardation assays were performed as described by O'Brien et al. (1990), with $150 \mathrm{mM} \mathrm{KCl}$ and $3 \mu \mathrm{g}$ of poly[d(IC)] as nonspecific competitor. Samples were run on $4 \%$ polyacrylamide gels (acrylamide/bisacrylamide, $25: 1$ ) at $25 \mathrm{~mA}$ for $2 \mathrm{hr}$ in a buffer containing $45 \mathrm{~mm}$ Tris (pH8.0), $45 \mathrm{~mm}$ borate, and $1 \mathrm{mM}$ EDTA. Gels were dried and visualized by autoradiography.

\section{Acknowledgments}

We are grateful to Neal Copeland and Deborah Swing for microinjection of the constructs N2-Apa and N2-Bam, and Thomas Saunders for microinjection of AGH3 and ATK1. We thank Sally Camper, Kenneth Paigen, Diane Robins, and Jack Dixon for helpful discussions. This work was supported in part by National Institutes of Health grants GM24872 and DK36089. C.-N. Ting was the recipient of a predoctoral fellowship from the Michigan Center for Cancer Research.

The publication costs of this article were defrayed in part by payment of page charges. This article must therefore be hereby marked "advertisement" in accordance with 18 USC section 1734 solely to indicate this fact.

\section{References}

Adler, A., A. Scheller, Y. Hoffman, and D.M. Robins. 1991. Multiple components of a complex androgen-dependent enhancer. Mol. Endo. 5: 1587-1596.

Ann, D.K. and D.M. Carlson. 1985. The structure and organization of a proline-rich protein gene of a mouse multiple gene family. I. Biol. Chem. 260: 15863-15872.

Blobel, G. and V.R. Potter. 1966. Nuclei from rat liver: Isolation method that combines purity with high yield. Science 154: 1662-1665.

Boer, P.H., C.M. Adra, F.-F. Lau, and M.W. McBurney. 1987. The testis-specific phosphoglycerate kinase gene Pgk-1 is a recruited retroposon. Mol. Cell. Biol. 7: 3017-3112.

Dahl, H.H., R.M. Brown, W.M. Hutchison, C. Maragos, and G.K. Brown. 1990. A testis-specific form of the human pyruvate dehydrogenase $\mathrm{El}$ alpha subunit is coded for by an intronless gene on chromosome 4. Genomics 8: 225-232.

DeNoto, F.M., D.D. Moore, and H.M. Goodman. 1981. Human growth hormone DNA sequence and mRNA structure possible alternative splicing. Nucleic Acids Res. 9: 3719-3730.

Dignam, J.D., R.M. Lebowitz, and R.G. Roeder. 1983. Accurate transcription initiation by RNA polymerase II in a soluble extract from isolated mammalian nuclei. Nucleic Acids Res. 11: 1475-1489.

Dombroski, B.A., S.L. Mathias, E. Nanthakumar, A.F. Scott, and H.H Kazazian Jr. 1991. Isolation of an active human trans- posable element. Science 254: 1805-1808.

Emi, M., A. Horii, N. Tomita, T. Nishide, M. Ogawa, T. Mori, and K. Matsubara. 1988. Overlapping two genes in human DNA: A salivary amylase gene overlaps with a gamma-actin pseudogene that carries an integrated human endogenous retroviral DNA. Gene 62: 229-235.

Evans, J.P. and R.D. Palmiter. 1991. Retrotranspostion of a mouse L1 element. Proc. Natl. Acad. Sci. 88: 8792-8795.

Groot, P.C., M.J. Bleeker, J.C. Pronk, F. Arwert, W.H. Mager, R.J. Planta, A. W. Eriksson, and R.R. Frants. 1989. The human alpha amylase multigene family consists of haplotypes with variable numbers of genes. Genomics 5: 29-42.

Groot, P.C., W.H. Mager, and R.R. Frants. 1991. Interpretation of polymorphic DNA patterns in the human $\alpha$-amylase multigene family. Genomics 10: 779-785.

Gumucio, D.L., K. Wiebauer, R.M. Caldwell, L.C. Samuelson, and M.H. Meisler. 1988. Concerted evolution of human amylase genes. Mol. Cell. Biol. 8: 1197-1205.

Hayashi, Y., M. Fukayama, M. Koike, and T. Nakayama. 1986. Amylase in human lungs and the female genital tract. Histochemistry 85: 491-496.

Howard, G., P.R. Keller, T.M. Johnson, and M.H. Meisler. 1989. Binding of a pancreatic nuclear protein is correlated with amylase enhancer activity. Nucleic Acids Res. 17: 81858195.

Jones, J.M., S.A. Keller, L.C. Samuelson, L. Osborn, M.P. Rosenberg, and M.H. Meisler. 1989. A salivary amylase transgene is efficiently expressed in liver but not in the parotid gland of transgenic mice. Nucleic Acids Res. 17: 6613-6623.

Kim, H.-S. and N. Maeda. 1986. Structure of two HaeIII-type genes in the human salivary proline-rich protein multigene family. I. Biol. Chem. 261: 6712-6718.

Larson, E., N. Kato, and M. Cohen. 1989. Human endogenous proviruses. Curr. Top. Microbiol. Immunol. 148: 115-132.

Matsumine, H., M.A. Herbst, S.-H. Ignatius Ou, J.D. Wilson, and M.J. McPhaul. 1991. Aromatase mRNA in the extragonadal tissues of chickens with the henny-feathering trait is derived from a distinctive promoter structure that contains a segment of a retroviral long terminal repeat. J. Biol. Chem. 266: 19900-19907.

McCarrey, J.R. and K. Thomas. 1987. Human testis-specific PGK gene lacks introns and possesses characteristics of a processed gene. Nature 326: 501-505.

McKnight, S.L. 1982. Functional relationships between transcriptional control signals of the thymidine kinase gene of herpes simplex virus. Cell 35: 531-538.

Meisler, M.H. and D.L. Gumucio. 1986. Salivary amylase: Evolution and tissue-specific expression. In Molecular and cellular basis of digestion, (ed. P. Desnuelle, H. Sjöström, and O. Norén). pp. 457-466. Elsevier Biomedical Press. Amsterdam.

Nishide, T., M. Emi, Y. Nakamura, and K. Matsubara. 1986. Corrected sequences of cDNAs for human salivary and pancreatic $\alpha$-amylase. Gene 50: 371-372.

O'Brien, R.M., P.C. Lucas, C.D. Forest, M.A. Magnuson, and D.K. Granner. 1990. Identification of a sequence in the PEPCK gene that mediates a negative effect of insulin on transcription. Science 249: 533-537.

Osborn, L., M.P. Rosenberg, S.A. Keller, and M.H. Meisler. 1987. Tissue-specific and insulin-dependent expression of a pancreatic amylase gene in transgenic mice. Mol. Cell. Biol. 7: 326-334.

Rabson, A.B., P.E. Steele, C.F. Garon, and M.A. Martin. 1983. mRNA transcripts related to full-length endogenous retroviral DNA in human cells. Nature 306: 604-607.

Repaske, R., P.E. Steele, R.R. O'Neill, A.B. Rabson, and M.A. 
Martin. 1985. Nucleotide sequence of a full-length human endogenous retroviral segment. J. Virol. 54: 764-772.

Samuelson, L.C., K. Wiebauer, D.L. Gumucio, and M.H. Meisler. 1988. Expression of the human amylase genes: Recent origin of a salivary amylase promoter from an actin pseudogene. Nucleic Acids Res. 16: 8261-8275.

Samuelson, L.C., K. Wiebauer, C.M. Snow, and M.H. Meisler. 1990. Retroviral and pseudogene insertion sites reveal the lineage of human salivary and pancreatic amylase genes from a single gene during primate evolution. Mol. Cell. Biol. 10: $2513-2520$.

Scannapieco, F.A., K. Bhandary, N. Ramasubbu, and M.J. Levine. 1990. Structural relationship between the enzymatic and streptococcal binding sites of human salivary alphaamylase. Biochem. Biophys. Res. Comm. 173: 1109-1115.

Schibler, U. and F. Sierra. 1987. Alternate promoters in developmental gene expression. Annu. Rev. Genet. 21: 237-257.

Schibler, U., A.-C. Pittet, R.A. Young, O. Hagenbuchle, M. Tosi, S. Gellman, and P.K. Wellauer. 1982. The mouse $\alpha$-amylase multigene family: Sequence organization of members expressed in the pancreas, salivary gland and liver. J. Mol. Biol. 155: $247-266$

Shaw, P. and U. Schibler. 1986. Structure and expression of the parotid secretory protein gene of mouse. I. Mol. Biol. 192: $567-576$.

Stavenhagen, J.B. and D.M. Robins. 1988. An ancient provirus has imposed androgen regulation on the adjacent mouse sexlimited protein gene. Cell 55: 247-254. 


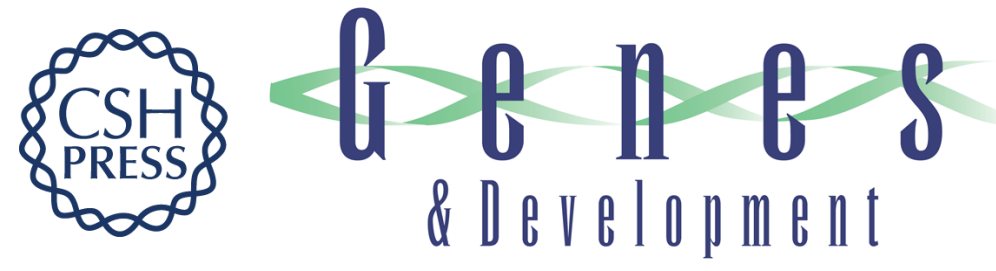

\section{Endogenous retroviral sequences are required for tissue-specific expression of a human salivary amylase gene.}

C N Ting, M P Rosenberg, C M Snow, et al.

Genes Dev. 1992, 6:

Access the most recent version at doi:10.1101/gad.6.8.1457

References This article cites 33 articles, 11 of which can be accessed free at: http://genesdev.cshlp.org/content/6/8/1457.full.html\#ref-list-1

License

Email Alerting

Service

Receive free email alerts when new articles cite this article - sign up in the box at the top right corner of the article or click here.

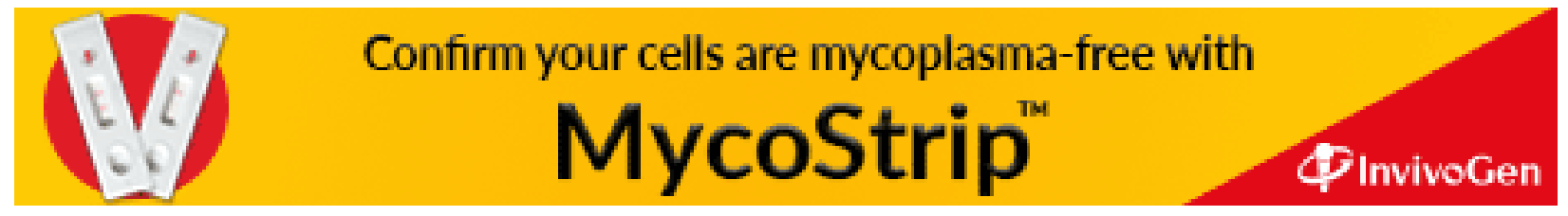

